\title{
UKRAINOS DEMOKRATIZACIJOS- DEDEMOKRATIZACIJOS YPATUMAI
}

\author{
Konstantinas Lotiuk \\ Klaipedos universitetas
}

\begin{abstract}
Anotacija
Šiandieniniuose politinių režimų ir demokratijų tyrimuose gausu ne tik demokratizacijos, bet ir dedemokratizacijos procesų ịžvalgų. Aktualus yra naujujų demokratijų likimas. Straipsnio fokusas - Ukrainos politinio režimo raida. Formaliai Ukraina pripažįstama kaip demokratijos atributus pozicionuojanti valstybè, tačiau realiai demokratija šalyje susiduria su egzistenciniais iššūkiais. Remiantis atliktu demokratijos situacijos Ukrainoje tyrimu, straipsnyje analizuojamas demokratizacijos ir dedemokratizacijos procesų ryšys šioje vienoje didžiausių Europos valstybių. Atkreipiamas demesys ị hibridinio politinio režimo perspektyvą, analizuojant ne tik demokratizacijos ir dedemokratizacijos procesų vienas kito neigimą, bet ir jų koegzistavimą analizuojant hibridinio politinio režimo istoriškumą, kontekstualumą bei šiuolaikinị tinkamumą.

PAGRINDINIAI ŽODŽIAI: demokratizacija-dedemokratizacija, hibridinis politinis režimas, vidiniai ir išoriniai politinio režimo veiksniai, Ukraina.
\end{abstract}

\begin{abstract}
There are plenty of insights not only in democratisation but also in de-democratisation in today's research into political regimes and democracy. The fate of new democracies is actual and relevant. The focus of this article is the evolution of Ukraine's political regime. Formally, Ukraine is recognised as a country positioning the attributes of democracy. Despite this, the democracy there is facing existential challenges. On the basis of the research conducted into the state of democracy in Ukraine, the connection between processes of democratisation and de-democratisation is analysed in this country, one of the largest in Europe. Attention is paid to the perspective of the hybrid political regime, analysing not only the denial of each other in processes of democratisation and de-democratisation, but also their coexistence, analysing the historicity, contextuality and modern suitability of the hybrid political regime.

KEY WORDS: democratisation, de-democratisation, hybrid political regime, internal and external factors of political regime, Ukraine.
\end{abstract}

DOI: http://dx.doi.org/10.15181/tbb.v86i1.2264

\section{Ivadas}

Ukraina, kaip demokratizacijos-dedemokratizacijos atvejo metodo objektas, yra pagrịstai vertingas pasirinkimas. Siekiant toliau konstruoti ir operacionalizuoti demokratizacijos ir dedemokratizacijos (D-D) ryšio teorinị modelį, ši šalis yra tinkamas pavyzdys, galintis tapti Vidurio Rytų Europos politinès raidos analizès prototipu (?), demokratijoms pastaruoju metu patiriant vis daugiau iššūkių.

1989-1991 metai daugeliui Vidurio Rytų Europos regiono šalių istorinès perspektyvos pasirinkimo požiūriu tapo lemtingi. Žinia, netrukus demokratinio tranzito 
teleologiją pakeitė alternatyvi transformatologija. Ukrainoje tik $2004 \mathrm{~m}$. prasidèjusi Oranžinè revoliucija inspiravo pirmuosius prodemokratiškus ir provakarietiškus procesus, kurie èmė slūgti po $2010 \mathrm{~m}$. Prorusiškas akcentas lėmè $2014 \mathrm{~m}$. Euromaidano revoliuciją. Šiuo požiūriu susidūrẻ prorusiškos ir provakarietiškos politinès krypties realybès. Revoliucija tapo iššūkiu politiniu, socialiniu, ekonominiu ir net kariniu požiūriu. 2004-2014 m. žymèjo demokratizacijos siekius, 2008-2010 m. - nusivylimą demokratizacijos procesų neparèmus juos institucionalizuojant, pažabojant korupcijos ir mažinant kitus neigiamus indeksus.

2019-2020 m. Ukrainoje ịvyko pirmieji taikūs valdžios perdavimo procesai. Šalies prezidentu tapus Volodymirui Zelenskiui, nepaisant po to sekusių išankstinių Aukščiausiosios Rados rinkimų, legitimių opozicijos priekaištų, pokyčiai tiek parlamentiniu, tiek prezidentiniu ar vietos savivaldos lygmeniu vyko laikantis pagrindinių demokratinių atstovaujamosios valdžios kriterijų. Šiuo požiūriu igyvendintas vienas pagrindinių demokratijos atributų - reguliari, konkurencinëje aplinkoje vykstanti, taiki politinès valdžios kaita. Tai reikšmingi, bet veikiau formalūs procedūriniai procesai, tik iš dalies atskleidžiantys giluminị substancinị Ukrainos demokratijos būvị. Politinis pliuralizmas, valdžių atskyrimo laipsnis rodo, kad demokratija šalyje turi ne tik jos kūrimo, bet ir erozijos požymių.

Mokslinė problema. Šiandieniniuose politinių režimų tyrimuose vis dažniau vartojami hibridinio politinio režimo terminai - ne tik demokratizacijos ir dedemokratizacijos perskyrimo, bet ir jų koegzistavimo kontekste, siekiant geresnio valstybès valdymo. Žinia, demokratija pasaulyje, ilgus metus neịveikus jai kilusių iššūkių ar nepaisant savo ribotų galimybių, patyre krizę. Moksliniuose tyrimuose gausu postdemokratijos ir neodemokratijos terminijos, vis dažnesnè nuoroda ị hibridinius politinius režimus. I demokratijos istorijos tęstinumą prasminga pažvelgti ne tik per neseniausiai teigtą jos „neišvengiamumo“, bet ir per jos realaus veiksmingumo prizmę. Kitaip tariant, ar naujosiomis demokratijomis save vadinančios šalys nesuka tradiciniu ,grynosios demokratijos“ keliu, kai demokratijos raidoje jau matomi esminiai pokyčiai? Juolab kad ir ịsigalëjusioje demokratijoje transformacijos procesai vyksta.

Tyrimo objektas - demokratizacijos ir dedemokratizacijos procesų ryšys Ukrainos politinio režimo raidoje.

Tyrimo tikslas - demokratizacijos ir dedemokratizacijos procesų Ukrainoje vertinimas, patvirtinant arba paneigiant keliamus mokslinio diskurso teiginiusprielaidas.

Straipsnyje pagrindžiami keli principiniai Ukrainos demokratizacijos ir dedemokratizacijos ypatumų mokslinio diskurso teiginiai-prielaidos:

1. Ukrainoje demokratizacijos ir dedemokratizacijos procesai sąveikauja ne tik kaip vienas kitą neigiantys ir naikinantys, bet ir kaip vienas kitą papildantys 
bei ribojantys vienas kito kraštutinumus, kurie trukdo politiniam stabilumui ir geram valstybès valdymui.

2. Demokratizacijos ir dedemokratizacijos procesų ryšys Ukrainoje priklauso tiek nuo vidinès, tiek nuo išorinès geopolitinès situacijos ir apibūdintinas hibridinio politinio režimo požymiais.

\section{Tyrimo metodologija}

Ne vienas geopolitikos, tarptautinių santykių ar sociologijos analitikas yra atkreipęs dèmesi ị demokratijos būklę Ukrainoje, jos perspektyvas, demokratizacijos situaciją. Šiame straipsnyje teorinès Ukrainos D-D įžvalgos formuluojamos, remiantis C. Tilly'io (2003; 2007), T. Kuzio (1998), L. Diamond'o (1996), V. Laurẻno (2018) ir kitų mokslininkų tyrimais, kurių apibendrinimą autorius pradèjo savo ankstesnejje publikacijoje (Lotiuk, 2021).

Didelis dèmesys moksliniame diskurse skiriamas posovietinèje erdveje besivystančiam politinių režimų hibridiškumui, kai Ukraina pasitelkiama kaip hibridinio politinio režimo atvejis. Nors dabartinis hibridinio politinio režimo mokslinis apibūdinimas vis dar gana ribotas, pasitelkiame D-D ryšio teoretizavimo prieigą, o politinį režimą apibūdiname remdamiesi T. Colton'u (2018) ${ }^{1}$ : politinis režimas nustato, kas ir kaip gali naudotis valstybès galios šaltiniais, kaip tie, kurie tais galios šaltiniais naudojasi, elgiasi su tais, kurie tokios galios neturi. Vyraujantis hibridinio politinio režimo apibūdinimas: režimas yra hibridinis, nes apima tiek demokratinius (reguliarūs ir tiesioginiai rinkimai), tiek autoritarinius (represijos prieš politinius oponentus, opozicijos suvaržymai, žiniasklaidos kontrolè) atributus (Karl, 1995; Diamond, 2002). Anot A. Cassani'io (2014), M. Mufti'io (2018), pats sutarimo moksliniame diskurse nebuvimas leidžia skirti kelias hibridinio politinio režimo variacijas: susilpnėjusi demokratija; susilpnèjęs autoritarizmas; trečiasis režimas tarp demokratijos ir autokratijos; atviras autoritarizmas. Taigi būtina plètoti diskusiją dèl hibridinio politinio režimo, kaip ,pilkosios zonos“, apibūdinimo nepakankamumo, pasitelkus pavienius hibridinio politinio režimo, kaip normalaus, apibūdinimo argumentus, kai hibridiškumu pasižymi ne tik paskiros naujosios demokratijos, bet hibridiškumo požymių vis daugiau atsiranda ir „senosiose“, t. y. ịsigalejusiose, demokratijose. Vertinga dekonstruoti hibridinio politinio režimo apibrèžtis, analizuoti jo istoriškumą, kontekstualumą ir šiuolaikinị tinkamumą. Bene labiausiai tam trukdo, kaip taikliai pastebèjo L. Diamond'as (2002), tokia dilema: viena vertus, demokratija dažniausia yra tas matas, pagal kurị brèžiami kitų politinių režimų kontūrai ir formuluojamos jų definicijos, antra

T. Colton'as savosios politinio režimo apibrėžties ištakas sieja su reprezentatyvia R. A. Fishman'o (1990) politinių režimų tyrimų apžvalga. 
vertus, vis dar trūksta bendro supratimo, kas yra pati demokratija. Kreipiamès ị laiko patikrintą J. J. Linz’o (1973, p. 34) ịžvalgą: vartoti demokratijos kategorijas apibūdinant hibridinius režimus neproduktyvu, nes taip mažinami demokratijos ir hibridinio politinio režimo skirtumai. Be to, tokius politinius režimus reikètų skirti nuo autoritarinių diktatūrų. Žinoma, galima juos papildyti būdvardžiais konkurencinis ar rinkiminis autoritarizmas (plg. Collier, Levitsky, 1997), bet to nepakanka, norint apibūdinti patị hibridini politinị režimą. Atsižvelgiant ị šios valdymo formos daugialypiškumą, vertinga skirti papildomas subkategorijas paties hibridinio valdymo apibrèžime. Bet kuriuo atveju siekiame analizuoti hibridinius politinius režimus jų tinkamumo, o ne jų a priori neigimo kontekste.

Straipsnyje remiamasi T. Kuzio (1998; 2005), analizavusio Ukrainos tranzitą iš sovietinès komunistinès valstybès ị demokratinę santvarką bei režimų tipologijos kaitą Ukrainoje, ịžvalgomis, L. Diamond'u (2002), pateikusiu hibridinių režimų prielaidas, egzistavimo sąlygas ir scenarijus. Akcentuojamas ir pačios Ukrainos mokslo bendruomenès ịdirbis: remiamasi V. Lebediuk'o (2018), Razumkov'o centro (2020) publikacijomis, kuriose pateikiami ne tik visuomenės apklausų Ukrainoje duomenys, bet ir politinių preferencijų spektras, siejant tai su politinio režimo jautrumu išoriniams ir vidiniams socialiniams, ekonominiams ịvykiams.

Empirinių D-D procesų Ukrainoje duomenų požiūriu kreiptasi ị The Economist Intelligence Unit (EIU), Freedom House (FHI) ir Bertelsmann Stiftung Transformation Index (BTI) Ukrainos demokratijos raidos vertinimo sekas. Be to, pasitelkti šių institucijų ekspertų demokratijos raidos Ukrainoje vertinimai. Kitas empirinių duomenų šaltinis - atlikta iš dalies struktūruota ekspertų apklausa. Apklausti devyni Ukrainos politinès raidos ekspertai, iš jų šeši - iš Ukrainos, trys - iš Lietuvos. Atliekant tyrimą siekta apklausti tuos Ukrainos ekspertus, kurie reziduoja skirtinguose šalies regionuose. Taip būtų pasiektas detalesnis minimų procesų analitinis pjūvis. Dalį ekspertų pasitelkus iš Lietuvos siekta palyginti ekspertinius požiūrius, taigi siekta analitinès prieigos įvairovès.

Tyrimo klausimyne, kurio pagrindu konstruotas iš dalies struktūruotas interviu, suformuluota ir pateikta devyniolika klausimų, suskirsčius juos ị tris grupes: demokratizacijos ir dedemokratizacijos sąveikavimo pobūdis Ukrainoje, vidiniai ir išoriniai D-D veiksniai. Taip struktūravus ekspertų kalbinimą galima apibrèžti bene labiausiai XXI amžiaus Ukrainos politinę raidą veikiančius aspektus. Tai leidžia pagrịstai analizuoti demokratijos raidą Ukrainoje, pastebint, kad net formaliai Ukrainą pripažinus kaip demokratijos atributus pozicionuojančią valstybę, realiai demokratijai šalyje neretai tenka priimti egzistencinius iššūkius. Skiriami Ukrainos politinès raidos etapai, išreiškiami konkrečiais metais: 1991-2004-20082014-2019 m. Kartu su ekspertais pripažistama, kad ši periodizacija nèra baigtinè, veikiau analitinè ir priklausanti nuo pačių ekspertų vertinimo. 
Taigi metodologinis tyrimo „trikampis“ yra toks: 1) remimasis demokratizacijos ir dedemokratizacijos procesų moksliniu diskursu; 2) politinès santvarkos Ukrainoje 2004-2020 m. indeksu kitimas, remiantis The Economist Intelligence Unit Democracy Index (EIU), Freedom House Index (FHI) ir Bertelsmann Stiftung Transformation Index (BTI) duomenimis; 3) ekspertu apklausa (interviu) Ukrainos demokratizacijos ir dedemokratizacijos procesu problematikos temomis.

\section{Ukrainos demokratizacijos-dedemokratizacijos vidiniai ir išoriniai veiksniai}

D-D procesus Ukrainoje reikšmingai veikia ne tik vidiniai, bet ir išoriniai veiksniai. Tad norint geriau pažinti D-D ryšio Ukrainoje ypatumus, būtina kompleksiškai analizuoti D-D vidinius ir išorinius veiksnius. Skirtini šie D-D vidiniai veiksniai: valstybės valdymo forma, demokratijos institucionalizacija, oligarchizacija ir korupcija, pilietinè visuomenè, prorusiškos jègos, nacionalizmas, postkomunistinè socialinè-ekonominè transformacija. Išorinius veiksnius galima apibūdinti kaip Rusijos, JAV ir ES įtakų konfigūraciją. Ukrainoje šių veiksnių kompleksas lemia hibridinio politinio režimo situaciją.

Remiantis EIU kriterijais, Ukrainos politinis režimas 2019 m. ̨̣vardytas kaip hibridinis, neatitinkantis net „demokratijos su trūkumais“ kriterijų. Tuo tarpu remiantis Freedom House indeksu (FHI), Ukraina nuolat išlieka (angl.) partly free, t. y. traktuojama kaip iš dalies laisva. Kartu, remiantis FHI duomenimis (žr. 1 pav.), ji pozicionuojama kaip valdoma hibridinio politinio režimo. Šis vertinimas nesikeičia nuo pat Euromaidano ịvykių 2014 m., nepaisant teigiamų teismų, vykdomosios ar leidžiamosios valdžių pokyčių. FHI leidžiamame kasmetiniame „Nations in Transit" leidinyje $2021 \mathrm{~m}$. Ukrainos demokratijos vertinimas pagal septynių balų skalę sumenko nuo 3,39 iki 3,36, dèl to teisme suspenduotos reformoms svarbios ịstatymų iniciatyvos, diskredituoti pažangūs valdininkai bei atmesti korupciją ịvardinantys verdiktai. Be to, išryškèjo įvairūs Konstitucinio teismo narių interesų konfliktai (Freedom House, 2021).

Galima teigti, kad Ukraina apsupta autoritarinių ar nevisiškai demokratinių režimų: Baltarusijoje (2020 m. - 7 balai, $2021 \mathrm{~m}$. - 5 balai) ir Rusijoje (2020 m. 7 balai, $2021 \mathrm{~m}$. -7 balai) konsoliduoti autoritariniai režimai, Lenkijos (2020 m. 65 balai, $2021 \mathrm{~m}$. -60 balų) ir Rumunijos (2020 m. - 57 balai, $2021 \mathrm{~m} .-57$ balai) nekonsoliduotos demokratijos, Vengrijos (2020 m. -49 balai, $2021 \mathrm{~m} .-45$ balai) ir Moldovos (2020 m. - 35 balai, $2021 \mathrm{~m}$. - 35 balai), remiantis FHI, hibridiniai politiniai režimai ir tik vienintelès Baltijos šalys - Lietuva (2020 m. - 77 balai, $2021 \mathrm{~m}$. 78 balai), Latvija (2020 m. - 80 balų, 2021 m. - 80 balų) ir Estija (2020 m. - 85 balai, $2021 \mathrm{~m}$. -84 balai) patenka ị konsoliduotų demokratijų valstybių grupę. 


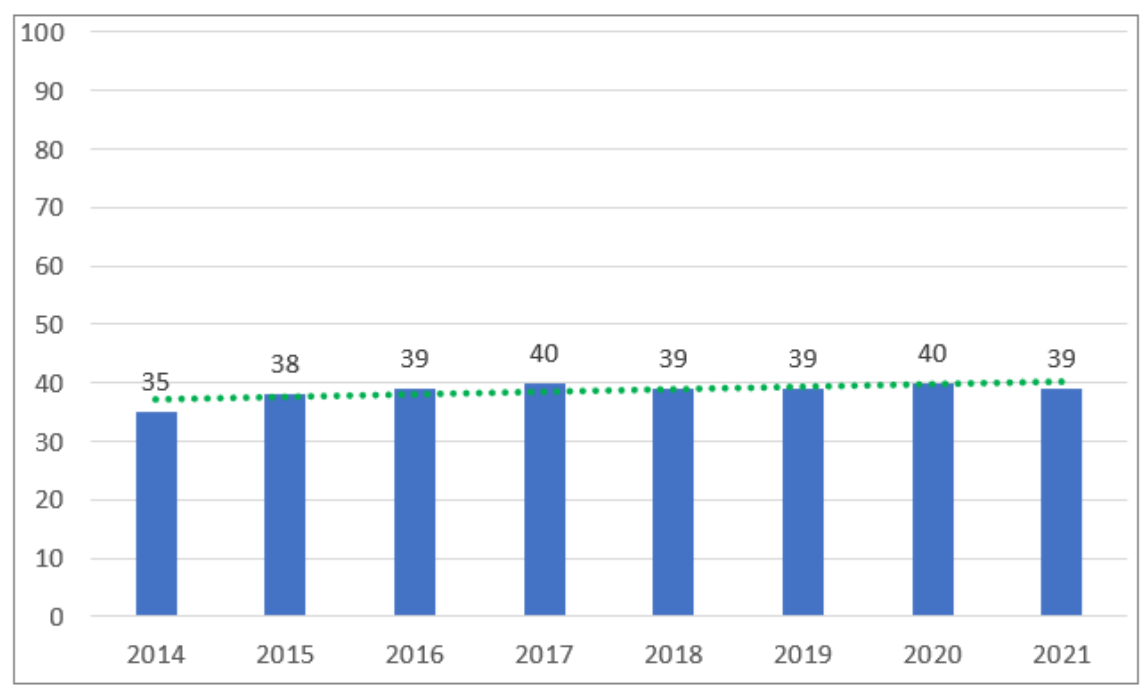

1 pav. Ukrainos demokratijos indekso pokyčiai

Šaltinis: Freedom House (2021)

„Bartelsmanno“ fondo 2020 m. pranešime teigiama: „Ukraina ir toliau patiria sunkumų, šalyje vykdydama įvairias reformas ar naudodama savo tarptautinę įtaką“ (Bartelsmann Stiftung, 2020). Laikotarpis po Euromaidano žymi dviejų jègų kovą dẻl ịtakos šalyje. Jas galima suskirstyti ị tas, kurios vykdydamos reformas siekia „perkrauti“ visą politinę šalies sistemą, ir tas, kurios nori išlaikyti turimą ịtaką.

BTI, analizuojantis, kaip besivystančios, tranzitinės šalys vykdo socialinius pokyčius siekdamos demokratijos ir rinkos ekonomikos, Ukrainą vertina (2 pav.) kaip besipriešinančią demokratinèms reformoms bei neišnaudojančią savo tarptautinio potencialo (Bartelsmann Stiftung, 2020). Šalies viduje nè vienas politinis žaidejjas demokratijai priešiškos retorikos nevartoja ir pozicionuoja prodemokratines vertybes. Vis dèlto pasitaiko atvejų, kada valdantysis elitas piktnaudžiauja savo politinėmis galiomis, tuo pamindamas pagrindinius demokratijos principus. Šiuo požiūriu laikotarpiu nuo Oranžinès revoliucijos (Viktoro Juščenkos prezidentavimo laikotarpiu) iki 2010 m., kai prezidentu išrinktas Viktoras Janukovičius, BTI indeksas Ukrainos atveju išliko stabilus. V. Janukovičiaus deklaruota laviravimo tarp Rytų ir Vakarų politika siejosi su didesne valdžios galių centralizacija, dedemokratizacija ir tik Euromaidano protestai, kaip vykdytos politikos išdava, tapo lūžiu ir minètas indeksas krito žemyn. Nors šio indekso pozicijos sustiprejjo, 2006 m. ir 2008 m. lygio jis vis dèlto nepasiekè. Taigi galima teigti, kad pats indeksas atskleidžia ribotą demokratiją, kai atotrūkis tarp deklaruojamos ir realios demokratijos išlieka gana didelis. 


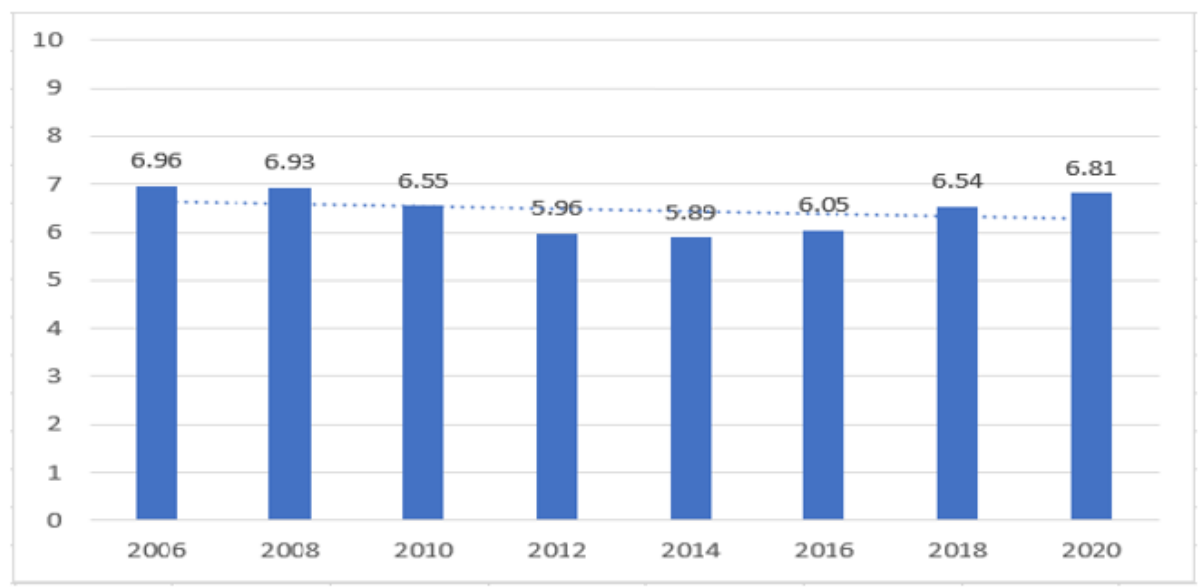

2 pav. Ukrainos transformacijos (demokratijos ir rinkos ekonomikos) indeksas Šaltinis: Bartelsmann Stiftung (2020).

Politinis pliuralizmas yra neatsiejamas demokratijos būklès, kuri grindžiama minètais indeksais, veiksnys. Net keli vektoriai atskleidžia pliuralizmo esmę. Pirma, valdžia pliuralizmo atveju turètų būti sutelkta ne vienos didelès elito grupès, o kelių grupių rankose. Antra, tos grupès turètų būti politiškai nepriklausomos, autonomiškos, jų veikimo principai neturètų priklausyti nuo aukštesnès valdžios leidimo, o tik nuo jų pačių gebejjimo sutelkti politinius išteklius. Trečia, kuo politinè sistema atviresnè piliečiams, tuo ji demokratiškesnè.

Daugelis apklaustų ekspertų atskleidžia tą Ukrainos postkomunistinę būseną, kuri reiškia, kad, kaip nurodoma ginamajame teiginyje, „tęsiasi sudètingas perejimo ị demokratiją procesas". Nè vienas ekspertas neteigia, kad Ukrainos postkomunistine būsena reiškia demokratijos konsolidaciją ir postkomunistinès transformacijos pabaigą, kai Ukrainos jau niekas nesieja su sovietine ir autokratine praeitimi. Vis dèlto dalis ekspertų Ukrainos postkomunistinę transformaciją apibūdina kaip ,ǐšalusi perejimą" iš autoritarinès komunistinès ị demokratinę erdvę. Taigi teigia, kad perspektyvos neaiškios, tikètina, jog nedemokratinès.

Mums ypač aktualiu D-D ryšio klausimu ekspertų nuomonių pasiskirstymas leidžia suformuluoti tarpinius apibendrinimus: dalis ekspertų svarsto D-D ryšio abipusiškumą, kai demokratizacijos ir dedemokratizacijos procesai vienas kitą papildo bei riboja kraštutinumus, kurie trukdo politiniam stabilumui ir geram valstybės valdymui. Pastebètina, kad pastarosios pozicijos laikosi visi ekspertai iš Lietuvos. Tuo tarpu ekspertų iš Ukrainos nuomonès išsiskyrè, o dalis aiškaus atsakymo ị klausimą taip ir nepateikè. Tradicini požiūrị ị D-D ryši, kai demokratizacija ir dedemokratizacija suprantama kaip vienas kitą neigiantys ir naikinantys procesai, 


\section{UKRAINOS DEMOKRATIZACIJOS-DEDEMOKRATIZACIJOS YPATUMAI}

palaiko tik trečdalis ekspertų, visi - iš Ukrainos. Svarbu ir tai, kad vyrauja ekspertu nuomoné, jog D-D procesų ryšys Ukrainoje priklauso tiek nuo vidinių, tiek ir nuo išorinių veiksnių, apskritai nuo geopolitinès situacijos.

\begin{tabular}{|c|c|c|c|c|c|c|}
\hline \multirow[b]{2}{*}{ 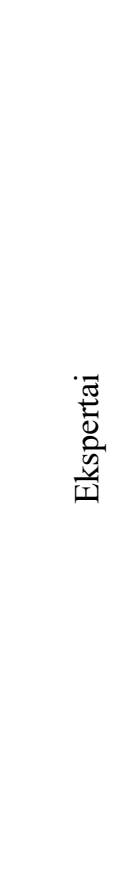 } & \multicolumn{2}{|c|}{$\begin{array}{c}\text { D-D procesų sąveika } \\
\boldsymbol{K} \boldsymbol{Y}\end{array}$} & $\begin{array}{l}\text { D-D pro- } \\
\text { cesų ryšys } \\
\text { Ukrainoje } \\
\text { priklauso } \\
\text { tiek nuo } \\
\text { vidinių, } \\
\text { tiek nuo } \\
\text { išorinių } \\
\text { veiksnių }\end{array}$ & $\begin{array}{l}\text { Ar Ukraina } \\
\text { demokratinè } \\
\text { šalis? } \\
\text { Kokia valsty- } \\
\text { bès valdymo } \\
\text { forma? }\end{array}$ & $\begin{array}{l}\text { Ar tik } \\
\text { demo- } \\
\text { kratiniai } \\
\text { procesai } \\
\text { būdingi } \\
\text { šalies } \\
\text { politinei } \\
\text { transfor- } \\
\text { macijai? }\end{array}$ & $\begin{array}{l}\text { Ukrainoje } \\
\text { vykstančių } \\
\text { politinių } \\
\text { procesų } \\
\text { demokra- } \\
\text { tiškumo } \\
\text { laipsnis }\end{array}$ \\
\hline & $\begin{array}{l}\text { Kaip } \\
\text { vienas } \\
\text { kitą nei- } \\
\text { giantys } \\
\text { ir naiki- } \\
\text { nantys }\end{array}$ & $\begin{array}{l}\text { Kaip vienas } \\
\text { kitą papil- } \\
\text { dantys bei } \\
\text { ribojantys } \\
\text { tuos vienas } \\
\text { kito kraštuti- } \\
\text { numus, kurie } \\
\text { trukdo politi- } \\
\text { niam stabilu- } \\
\text { mui ir geram } \\
\text { valstybės } \\
\text { valdymui }\end{array}$ & \multicolumn{3}{|c|}{$\begin{array}{l}\text { Taip - X } \\
\mathrm{Ne}-0 \\
\\
\mathrm{P} \text { - prezidentizmas } \\
\mathrm{P}-\mathrm{P} \text { - parlamentinis-prezidentinis } \\
\mathrm{PAR} \text { - parlamentinè respublika } \\
\text { LA - linkęs ị autokratiją }\end{array}$} & \begin{tabular}{l}
$1-$ žemas \\
\hdashline$\ldots \ldots \ldots \ldots . .$. \\
$5-$ aukš- \\
tas
\end{tabular} \\
\hline E1 UKR & $\mathrm{X}$ & - & $\mathrm{X}$ & Iš dalies / P & 0 & 2 \\
\hline E2 UKR & - & - & 0 & X / P-P & 0 & 2 \\
\hline E3 UKR & - & $\mathrm{X}$ & $\mathrm{X}$ & $0 /$ PAR & 0 & 3 \\
\hline E4 UKR & - & - & $\mathrm{X}$ & X / P-P & 0 & 4 \\
\hline E5UKR & $\mathrm{X}$ & - & $\mathrm{X}$ & Iš dalies & 0 & 3 \\
\hline E6 UKR & $\mathrm{X}$ & - & 0 & $0 /$ LA & 0 & 1 \\
\hline E7 LTU & - & $\mathrm{X}$ & $\mathrm{X}$ & Iš dalies / P & 0 & 3 \\
\hline E8 LTU & - & $\mathrm{X}$ & $\mathrm{X}$ & $\mathrm{X} / \mathrm{P}-\mathrm{P}$ & 0 & 3 \\
\hline E9 LTU & & $\mathrm{X}$ & $\mathrm{X}$ & Iš dalies /P-P & 0 & 3 \\
\hline
\end{tabular}

3 pav. Tyrimo metu vykdytos ekspertų apklausos duomenys

Šaltinis: sudaryta autoriaus.

Atsakydami ị klausimą dèl politinio pliuralizmo Ukrainoje (3 pav.) penki ekspertai pažymėjo atsakymą iš dalies, du atsakè taip. Anot V. Lebediuk'o (2018), formaliai Ukrainoje politinis pliuralizmas egzistuoja, tačiau politinè konkurencija, kuria grindžiamas politinis pliuralizmas, ribota. Pats politinis pliuralizmas nëra beribis, nes po „orumo revoliucijos“ ir Rusijos agresijos rytinejje Ukrainoje išryškejjo proeuropietiškų jëgų poreikis (Lebediuk, 2018). Vis dèlto partijų šalyje 
yra nemažai, ką implikuoja nuo tuo metu politinèje erdvejje tvyrančių tendencijų priklausantis naujų partijų ar susibūrimų atsiradimas. Šiuo požiūriu Ukrainoje dar nèra partinès sistemos institucionalizacijos, o pati institucionalizacija, kaip fenomenas, reformu pagrindu yra ne tiek naujas, kiek pastovus, komplikuotas ir dedemokratizuojančių veiksnių (korupcijos, nepotizmo, oligachizacijos, atskaitomybės stokos ir pan.) veikiamas procesas. C. Tilly'io (2007) teigimu, dedemokratizacija pasireiškia kaip nelygybės masto augimas ir viešajai politikai nepaklūstančių galios centru atsiradimas. Galima teigti, kad ten, kur partinè sistema stabili, ji yra institucionalizuota. Šie procesai rodo geresnès viešosios politikos, mažesnio populizmo galimybę.

Ukrainoje demokratijos atributų institucionalizavimą geriausiai atskleidžia struktūrinès transformacijos. Visų pirma ši decentralizacijos reforma reikšmingą teisių ir laisvių dali perdavè regiono ir vietos elitui. Šiuo atveju kalbama būtent apie atstovaujamają demokratiją, mažiau akcentuojant tiesioginę ir dalyvaujamają demokratiją. Antra, regioniniai skirtumai ir susiskaldęs tapatumas neleidžia formuotis vieningam elitui, kuris yra esminis kiekvieną režimą įtvirtinantis veiksnys. Skirtingai nuo kaimyninių šalių, Ukrainos elitas paveldejo fragmentišką struktūrą, tad sklandus demokratinių vertybių įtvirtinimas mažai tikètinas. Kol skirtingos elito grupès varžosi dèl ịtakos (ir rentos), nẻ viena jų negali monopolizuoti valdžios. Be to, institucionalizuotą valdžios monopoliją tramdo silpnosios politinès partijos ir riboti valstybès represiniai pajègumai. Trečia, stiprinami ryšiai tarp Ukrainos ir Vakarų (per ES ir Ukrainos asociacijos susitarimą, bevizị režimą), didejjanti priklausomybė nuo Vakarų finansinès bei saugumo paramos vertė Ukrainos elitą priimti naujus kovos su korupcija teisès aktus, steigti naujas institucijas. Institucinio spaudimo pasekmes Vakarų šalys ne iš karto apčiuopia, bet net ir nereikšminga pažanga Ukrainoje kuriant demokratiją reiškia papildomas investicijas. Charizmatiško lyderio trūkumas, visuomeneje vyraujančios prodemokratinès nuotaikos ir trys išgyventos antiautoritarinių protestų bangos slopina dedemokratizacijos procesus. Vis dèlto būtent istoriškumas, kaip tik ir neleidęs įgyti daugiau demokratijos patirties, bei vèliau sekęs politinis izoliuotumas, ekonominè suirute, socialiniai-demografiniai iššūkiai šalies viduje inspiravo dalị pageidaujamų demokratinių procesų (Kuzio, 1998).

R. N. Stone'o teigimu, nuo pat Euromaidano protestų 2013-2014 m., Ukrainos pilietinè visuomenè turejo reikalų su nuolat tiek teigiamai, tiek neigiamai besikeičiančia politine konjunktūra. Teigiamas aspektas - ne tik išaugęs visuomenès narių pilietiškumas, bet ir daugelio kitų visuomenès narių ịsitraukimas ị visuomeninę veiklą. Karinis konfliktas Rytų Ukrainoje paskatino ukrainiečius tapti savanoriais, aukoti labdarai, palaikyti tiek kariuomenę, tiek nuo konflikto nukentejusius žmones. Valstybė, ị parlamentą atèjus naujiems nariams, kreipèsi ị pilietinę visuomenę, 
siekdama pasitarti dèl būtinų reformų. Kartu, didejant politinei konkurencijai, ị politiką atejus kai kuriems aktyvių bendruomenių lyderiams, susidare įtampa tarp valstybės ir pilietinès visuomenès (Stone, 2019).

Remiantis Razumkov'o centro bei Demokratinių iniciatyvų fondo duomenimis, kas trečias ukrainietis (32,8 proc.) pažymi, kad reguliariai dalyvauja savo bendruomenès gyvenime, visuomeninių organizacijų veikloje dalyvauja šiek tiek mažesné piliečių dalis (16,9 proc.). Daugelis respondentų (63,5 proc.) nepasirengę aukoti savo laisvès didesnio šalies saugumo ir klestejjimo labui. 47,8 proc. respondentų teigè, kad valstybè turi prisiimti atsakomybę už kiekvieno piliečio gerovę, 30,0 proc. pripažino, kad už savo gerovę yra atsakingi patys. 63,3 proc. pasisakè už Ukrainos įstojimą į Europos Sajungą, 49,8 proc. - už Ukrainos ịstojimą į NATO (Razumkov Center, 2020; DIF, 2020). Apklausos rezultatai atskleidžia įdomią situaciją, kai 62 proc. ukrainiečių nepatenkinti demokratijos raida šalyje, bet maždaug 60 proc. mano, kad „tvirta ranka“ padarys šalyje tvarką. Toks dvilypis nusiteikimas demokratijos kontekste yra gana ịprastas posovietinio ir Rytu Europos bloko šalyse, kada visuomenė nori tokios demokratijos, kuri suteiktų galimybę kuo daugiau atstovų rinkti tiesiogiai. Be to, anot Ch. Tilly'io (2003), tose visuomenèse, kuriose dalyvavimas viešojoje politikoje skatinamas, kategorinė nelygybè, arba dedemokratizacija, užima tolygiai žemèjančią padètị. Šiuo požiūriu vertinga apžvelgti, koks Ukrainoje žodžio, susirinkimų ir spaudos laisvès lygis, ar ji neribojama.

Atlikus tyrimą paaiškejo, kad respondentai bene vieningai sutaria, jog Ukrainoje vis dažniau ribojama žodžio laisvè. Remiantis Ukrainos Masinès informacijos instituto ekspertais, žodžio laisvès pažeidimų skaičius auga (IMI, 2021). Pagrindinès žodžio laisvès pažeidimų kategorijos: trukdymas teisètai žurnalistinei veiklai, grasinimai, sumušimai. Instituto stebėsenos duomenimis, padaugejjo cenzūravimo, žiniasklaidos priemonių savininkų cenzūros griežtinimo atvejų. Kita vertus, žodžio laisvès ribojimas, nors fundamentaliai prieštarauja pagrindiniams demokratijos principams, neatsiejamas nuo nacionalizmo fenomeno, kuris - atvirkščiai, gali daryti ịtaką demokratijos institucionalizacijai. Anot E. Yazici'io (2019), pats savaime nacionalizmas žodžio ar susirinkimų laisvei neprieštarauja, bet dèl valstybẻs saugumo ar nacionalinès vienybės žodžio laisvė gali būti laikinai suspenduota. Fundamentaliu požiūriu, kaip teigia N. Statkus (2003, p. 23), nacionalizmą vertą apibrēžti kaip idealą ar ideologiją, teigiančią, kad etninès bei politinès ribos turi sutapti ir kad etniškai vienalytė valstybè yra optimali politinès organizacijos forma, o naciją - kaip politiškai organizuotą etninę grupę, siekiančią išsikovoti ar išlaikyti politinę autonomiją arba nepriklausomą valstybingumą.

Ukrainoje, anot tyrime dalyvavusių ekspertų (Fedorenko, Rybiy, Umland, 2016), nacionalizmas tam tikru mastu veikia demokratijos (ne)institucionalizacijos procesus. Po Oranžinès revoliucijos Ukrainoje ịvyko ideologinis susiskaldymas. 


\section{Konstantinas Lotiuk}

Konkurencija tarp oponuojančių grupių susiformavo šiais klausimais: (a) proprezidentinė ar proparlamentinė pozicija; (b) proeuropietiškumas ar prorusiškumas; (c) etnonacionalizmas ar neosovietizmas. Be to, stabilizavosi suskaidymas i pietryčiu ir šiaurès vakarų rinkimų makroregionus. Ideologinis šio laikotarpio bruožas - elektorato padalijimo ị rytų ir vakarų ịveikimas. Tai pastebėta $2014 \mathrm{~m}$. ir patvirtinta 2019 m. Ukrainos rinkimų ekosistema pasikeite, praradus rinkejjus Kryme ir dali jų Donecke bei karo sukrèstus rinkẻjus pietryčiuose. Kartu nacionalistinès grupès perèmé oficialios atminties politikos bei švietimo ịstaigu kontrolę ir taip igijo galimybę ,prastumti“ savo darbotvarkę (Касьянов, 2018). Šiuo metu Ukrainos demokratija tapo nebaigto karo ir skurdo įkaite. Politinių ir pilietinių laisvių ateitis priklauso nuo to, kaip greitai bei teisingai bus atkurta taika ir prasidess tautinis susitaikymas, namų ūkiai Ukrainoje galès gyventi geriau. Pasiekus šiuos tris pagrindinius tikslus, bus įmanoma ir tvari bei nuolatinè demokratijos raida.

Pastangos sukurti institucijas, kurios ribotų ir naikintų oligarchinį-klaninị valdymą, buvo viena iš Ukrainos Konstitucijos pokyčių dichotomijų. Šalies žiniasklaidos diskurse išties daug kalbama apie oligarchus ir jų įtaką šalies gyvenimui. Ukrainoje nuolat rengti sąmokslai tarp politikų arba tarp politikų ir oligarchų, bet né vienam jų nebuvo lemta „žaisti pagal taisykles“. Tuo tarpu oligarchų sąmokslai paaiškina beveik visų Ukrainos prezidentų rinkimų rezultatus, įskaitant ir V. Zelenskio pergalę 2019 metais. Oligarchinis konsensusas šiuo atveju preziumuoja sąmokslą dèl valdžios padalijimo, visų pirma dèl kito teisių perėmèjo, ịpèdinio išrinkimo.

Isigalëjusi kategorinè nelygybė, kalbant apie visuomenę, skatina valstybès palankumą turinčias grupes naudotis valstybès ištekliais savo reikmèms, taigi iškreipti aristokratijos principus, Aristotelis tai vadino oligarchija (Tilly, 2000). Tokio sąmokslo dèka išrinktas ịpėdinis tampa oligarchų ịkaitu, neva paaiškindamas savo prigimtinę laisvę kovoje su korupcija ir nenuoseklumą įgyvendinant reformas. Tiesą sakant, Ukrainoje jokio konsensuso tarp oligarchų / elito dar nebuvo ir artimiausiu metu nenusimato. Ukrainos politika svyruoja tarp priverstinių kompromisų, kai elito dauguma laikinai pripažįsta pagrindinio žaidèjo teisę ị valdžią ir „visų kovą prieš visus“. Kol kovos objektas bus turto paskirstymas, o ne sąveikos principai ir taisyklès, tol bet koks tvarus kompromisas (elito konsensusas) iš esmès bus neịmanomas. Būtent dèl to oligarchinè konkurencija yra būdingas Ukrainos politikos bruožas (priešingai nei Rusijoje ar Baltarusijoje, kur tokia konkurencija ribojama ir vyksta ne dèl turto, o dèl atsidavimo šalies globejjui). Tai pasakytina apie visus prezidentus, pradedant Leonidu Kučma, ir nèra jokių požymių, kad V. Zelenskio atveju bus kitaip. Potencialiai ydinga yra tai, kad oligarchų vidiné kova silpnina valstybę, bet gerai, kad oligarchinè konkurencija leidžia keisti valdžią ir tramdo slinkimą autoritarizmo link. 
Politikai bando pasinaudoti šia padètimi, kuri yra tarsi derlinga dirva manipuliacijoms. Pilietinė visuomenè pakeitè tam tikras valstybės funkcijas, ypač 20142017 metais. Tai buvo ypač akivaizdu augant savanorių judejjimui ir palaikant Ukrainos kariuomenę šalies rytuose. Be to, daugelis pilietinès visuomenès atstovų priimti ị valdžios institucijas, bet visa tai vyko fragmentiškai, tad jų įtaka neinstitucionalizuota. Ukrainoje išlieka didelis nepasitikejjimas politinėmis institucijomis (Prentice, 2018).

Visgi pagrindinis išorinis Ukrainos D-D veiksnys yra Rusijos, JAV ir ES įtaku konfigūracija. Rusijos vykdoma politika Ukrainos atžvilgiu nuo pat šalies nepriklausomybės paskelbimo susijusi su ekonomine, socialine, politine, karine ar apskritai geopolitine Rusijos erdviu politika. Z. Brzezinski'o (1994, p. 16) teigimu, „Rusija be Ukrainos nustoja buvusi imperija, o su sau pavaldžia Ukraina ji automatiškai ja tampa“. Tokia apibendrinanti definicija konceptualiai formuoja Rusijos požiūrị, kuris susiklosčius faktinėms aplinkybėms pasireiškia bene kiekviename paskirtų valdžių (teisminès, leidžiamosios ir vykdomosios) politikos kontekste. Galima teigti, kad Rusija yra suinteresuota priklausoma, nestabilia Ukraina, arba, remiantis FCI, žlugusios valstybès (angl. failed state) būviu.

Atlikus tyrimą aiškèja, kad šiandien Rusijos Ukrainos atžvilgiu vykdoma politika turi reikšmingą poveikį, nes Ukrainoje prorusiškų jègų ịtaka vis dar išlieka. Nors šios jẻgos nebèra konsoliduotos, tačiau, kaip rodo 2019 m. parlamento rinkimų rezultatai, jos gavo 13,05 proc. palaikymą. Vladimiro Putino valdomos Rusijos inicijuotas karas prieš Ukrainą lėmè šalies susivienijimą, tačiau Kremlius dar turi kur manevruoti, ypač remdamasis etnolingvistine korta. Vienas iš pavyzdžių - garsus Ukrainos oligarcho Viktoro Medvedčiuko (jo atžalos krikštatèvis yra V. Putinas) atvejis. V. Medvedčiuko požiūris ị Ukrainos ir Rusijos konflikto sprendimą, kaip teigia O. Carroll'as (2018), „nuosekliai palankus Maskvai ir keičiasi keičiantis Kremliaus pozicijai“. Prezidento rinkimuose 2019 m. V. Medvedčiukas palaikè kandidatą Jurijų Boiko, vieną iš partijos „Opozicinè platforma - už gyvenimą“ lyderių. Šiuo V. Medvedčiuko ir V. Putino planu siekiama stabdyti nacionalinio susivienijimo procesą.

Iki 2014 m. nemažai ukrainiečių, ypač gyvenančių Vidurio ir Pietryčių Ukrainoje, laikèsi daugiau ar mažiau palankių Rusijai nuostatų arba geopolitikos klausimams buvo abejingi, o po $2014 \mathrm{~m}$. ịvykių visuomenès požiūris ị didžiąą kaimynę pakito labiau i neigiamą pusę. Dèl to ne tik sumenko prorusiškų politinių partijų bei idejų įtaka, ypač vakarų Ukrainoje, bet ir gana plačiai ịsitvirtino Rusijos, kaip „grèsmingo kito“, suvokimas. Nepaisant to, ne visuomenès, kaip tokios, o būtent sprendimų prièmimo institucijų kontekste galima pastebėti, kad didžiulès dalies žaidèjų interesai vis dar siejami su šalies šiaurine kaimyne, taigi vèl grị̌tame prie laviravimo tarp suinteresuotų šalių klausimo. 
Tyrimas atskleidè, kad Vakaru palaikymas yra lyg demokratizacijos procesų katalizatorius, garantas ir „stebėtojas“ viename. Ypač aktualus yra ES vaidmuo, nes Ukrainos krizè prasidejo ES neịtikinus V. Janukovičiaus pasirašyti asociacijos sutarties. Beje, tuo metu ES pirmininkavo Lietuva. Galima klausti, ar Ukrainos orientacijos ị ES likimas neprimena Turkijos atvejo? (Radeljić, 2021).

Laikantis ES asociacijos kriterijų, europinès integracijos atveju - Kopenhagos kriterijų, nustatomos užduotys, kurias vykdant lyg ir sudaromos teigiamos demokratizacijos sąlygos, kartu apsunkinami dedemokratizacijos procesai, tačiau bendra padètis išlieka hibridinio valdymo erdveje. Pati orientacija ị Vakarus, tvirtas, bent jau šiaurès atlantistinis (JAV, Turkijos), užnugaris - vienas svarbių demokratijos institucionalizaciją Ukrainoje lemiančiu veiksnių. ES ir Tarptautinio valiutos fondo finansinè parama (nebūtinai politinis palaikymas) mainais ị reformas verčia valdžią inicijuoti pokyčius, nes bet koks ,meilinimasis“ šaliai agresorei lems rinkejų praradimą. Tai rodo jau minètos visuomenès apklausos (angl. exit polls) ir galutiniai ịvairių lygių rinkimai.

\section{Ukraina: kokio hibridinio politinio režimo atvejis?}

Taigi turime sudètingą D-D procesų Ukrainoje labirintą, kuriame nepasiklysti gali padèti pasitelktas hibridinio politinio režimo analitinis instrumentas. Tačiau nepakanka pasakyti, kad demokratizacijos procesas Ukrainoje tęsiasi hibridinio politinio režimo aplinkoje, reikia apibūdinti konkrečias šio režimo charakteristikas ir galimai bent artimiausią jo ateitį.

Pats politinio režimo hibridiškumas yra santykinai ilgalaikès raidos rezultatas. Hibridinis režimas, kaip toks, ir jo stabilumas / efektyvumas Ukrainoje, kur demokratija dar gana ,jauna“, yra tiek numanomas, kiek tam yra pasiruošusi šalies visuomenè. Tokia valdymo forma savaime nera nei bloga, nei gera. Ji yra laikmečio, šiuo atveju - vienas iš dabartinių laikų globalizacijos ir geopolitinès situacijos inspiruojamų procesų rezultatų.

Specifinis oficialių ir neoficialių institucijų derinys (įskaitant konkurencinius rinkimus, teisès viršenybès stoką bei neformalios politikos vyravimą politiniame procese) Ukrainoje pasirodè esąs gana tvirtas politinis konstruktas. Šis hibridinis režimas susiformavo L. Kučmos valdymo laikais, išgyveno Oranžinę revoliuciją ir Euromaidaną. Elitas yra linkęs palaikyti neveikiančias institucijas, nes jos išlaiko ir net gausina jo išteklius. Tol, kol Ukrainos politinio režimo dinamikoje vyrauja hibridizacija, o ne demokratizacija ar autoritarizacija, hibridiškumas išlieka elito pageidaujama būsena (Смірнова, 2017, p. 70).

Ukrainoje nuo pat šaltojo karo pabaigos demokratijai taip ir nepavyko susitelkti. ,Istrigimas“ tarp demokratijos ir autokratijos yra vienas iš patekimo i „, „pilkają 
zoną" atvejų, tikintis, kad šie procesai tęsis tik tam tikrą laiką ir galiausiai baigsis arba demokratijos, arba autokratijos ịsigalejjimu. Vis dèlto yra manančiųu, kad hibridiniai politiniai režimai nèra nei atsitiktiniai, nei trumpalaikiai, o nauja stabilaus politinio režimo forma. V. Laurėnas tokią hibridinių politinių režimų perspektyvą sieja su fundamentinèmis dabarties visuomenių raidos aplinkybėmis ${ }^{2}$. Iš tikrujų vien tik terorizmo ir epidemijų prevencijos ar padarinių likvidavimo priemonès palieka demokratijai tik jos procedūrinès dimensijos perspektyvą, jeigu pastarosios neapribos konvencinio dalyvavimo politikoje slinkties protesto, dažnai nekonvencinio, politinio dalyvavimo, link. Taigi neišvengiama gyventojų komunikavimo ir judumo apskaita gerokai riboja demokratijos principų sklaidą ir numano dažniausia nedemokratinių, neliberalių kontrolès režimo priemonių taikymą.

Tuo tarpu, anot T. Kuzio (2005), kuris atstovauja vyraujančiai hibridinių politinių režimų, kaip neperspektyvios ir todèl laikinos (?) demokratinio bei autoritarinio valdymo jungties, sampratai, Ukrainoje galima pastebèti šešis hibridinio režimo požymius, kurie būdingi tiek L. Kučmos valdymo laikams, tiek mažai pakitusiai dabartinei realybei:

- valstybès piliečiai ne visiškai atstovaujami arba jų nuomonès (ypač vietos savivaldos lygmeniu) iš dalies ignoruojamos;

- mažas politinis aktyvumas, neskaitant dalyvavimo rinkimuose, kaip deleguojamosios demokratijos atributo;

- dažni įstatymo viršenybės pažeidimai arba manipuliavimas jais;

- rinkimų rezultatai piliečių akyse neatrodo legitimūs;

- mažas pasitikejjimas valstybès institucijomis;

- prasti rezultatai valstybès veiklos požiūriu.

Remiantis EIU, 2020 m. Ukrainoje, kaip vienoje iš hibridinio politinio režimo valstybių, buvo galima stebèti gerèjančius politinio pliuralizmo rezultatus. 2019 m. vykę rinkimai išryškino aukštesnius elektorato standartus, buvo sąžiningesni ir skaidresni. Šiuo požiūriu, nors šalies politinis spektras (provakarietiškas politinis sparnas, oligarchai ir prorusiškos politinès jègos) savo sudètimi išlieka iš esmès nepakitęs, o periodiniai visų valdžios lygių rinkimai neleidžia atsirasti žymesnėms autoritarizmo užuomazgoms, galima daryti išvadą, jog pats hibridiškumas Ukrainoje gali stiprèti.

Dar kartą pabrežtina, kad, anot V. Lebediuk'o, politinio režimo hibridiškumas Ukrainoje yra susidariusios politinès, socialinès-ekonominès ir geopolitinès aplin-

„Iš tikrujų socialinių hibridų randasi dèl dviejų pagrindinių aplinkybių: (1) Kaita visada yra trumpesnè ar ilgesné buvusių (esamų) ir naujų gyvenimo formų koegzistencija; (2) Siekiant šią koegzistenciją riboti laike, o spartejančios visuomenès apskritai „neturi laiko“, ryžtamasi holistiniams pokyčiams, bet tokių pokyčių šalininkų laukia netikètumas - galiausiai nežinoma, kaip vienų gyvenimo sričių institucijas pritaikyti prie kitų. Takiu būdu, visiškai „ne iš blogos valios“, susikuria hibridinès sociumo formos“ (Laurenas, 2017, p. 86). 


\section{Konstantinas Lotiuk}

kos išdava (Lebediuk, 2018). Bandymų keisti šalies institucinę sąrangą būta ne kartą, ypač prezidento galių išplètimo kontekste. Pati šalies valdymo forma yra parlamentinè-prezidentinè. Pastangos sukurti prezidentinio valdymo sistemą asocijuojasi su valdžios monopolizavimu. Kaskart, kai V. Janukovičius ar anksčiau L. Kučma bandè plèsti savo galias, parlamentas ir visuomenè tam trukdè. $2018 \mathrm{~m}$. Julijos Tymošenko išsakyta ideja dẻl parlamentinès sistemos su stipriu ministru pirmininku - kol kas neigyvendinamas projektas. Tai igyvendinti bus sunku dèl konkuruojančių elito grupių ir visuomenès palaikymo stokos. Nors dabartinis Ukrainos valdymo modelis toli gražu netobulas, ukrainiečiai yra linkę turèti padalytą vykdomają valdžią, kuri apsaugo nuo valdžios susikoncentravimo. Valdymo forma Ukrainoje keitèsi šešis kartus (1991, 1995, 1996, 2004, 2010 ir 2014 metais), tuo tarpu režimas, anot apklaustų ekspertų, pasikeite tik kartą. Šiuo požiūriu nuo autoritarinio režimo pereita prie hibridinio, kuriame ir vyksta šalies politiné evoliucija.

Kitų šalių - Vengrijos ir Lenkijos - atvejai leidžia teigti, kad vadinamoji ,pilkoji zona" tarp demokratijos ir autokratijos linkusi plèstis. Šiuo požiūriu naryste ES neneigia Vengrijos ir Lenkijos politinių režimų hibridiškumo, juolab kad pačiai ES būdingas demokratijos deficitas. Priešingai, Vengrijos ir Lenkijos išlikimas ES reiškia ne tik hibridinio politinio režimo tvarumą, bet ir erdvès jam suteikimą, legitimumą (Bozóki, Hegedűs, 2018). Taigi vis labiau plečiantis hibridiniams politiniams režimams, jie gali būti apibūdinami kaip forma, kuri vienu ar kitu atveju, atsižvelgiant ị valstybès ekonominę, socialinę ir politinę situaciją, gali būti net labiau logiška ir efektyvi nei konsolidacijos nepasiekiantis ,grynasis“ demokratinis politinis režimas.

\section{Išvados}

Negalètume sakyti, kad Ukrainoje vykstantys demokratizacijos ir dedemokratizacijos procesai vienas kitą kategoriškai neigia, bet nepakanka argumentų teigti, kad D-D ryšys kryptingai konstruojamas ir palaikomas siekiant tinkamesnio Ukrainos politinio valdymo. Situacija labiau primena tai, kas vadinama „pilkaja zona“. Šios situacijos konstatavimas patvirtina mūsų pirmosios prielaidos pirmają dali, kad Ukrainoje demokratizacijos ir dedemokratizacijos procesai sąveikauja ne tik kaip vienas kitą neigiantys ir naikinantys, bet ir kaip vienas kitą papildantys bei ribojantys tuos vienas kito kraštutinumus, kurie trukdo politiniam stabilumui ir geram valstybès valdymui. Ne tik geopolitinè ir karinio konflikto situacija, bet ir kiti vidiniai veiksniai, pirmiausia prorusiškų jègų potencialas ir pastangos, verčia Ukrainą riboti visiškos demokratijos politinio režimo institucionalizaciją. Šiuo 
požiūriu tvarus politinis režimas turi daugiau galimybių atsirasti dabartinès postdemokratijos sąlygomis.

Todèl mūsų antra prielaida, kad demokratizacijos ir dedemokratizacijos procesų ryšys Ukrainoje priklauso tiek nuo vidinès, tiek nuo išorinès geopolitinès situacijos ir apibūdintinas hibridinio politinio režimo požymiais, taip pat pasitvirtina tik kalbant apie jos pirmą dali, tuo tarpu antroji dalis taip tikslintina: Ukrainoje hibridinis politinis režimas netinkamas žvelgiant iš šalies spartesnès plètros pozicijų. Nors Ukrainoje egzistuojantis hibridinio politinio režimo atvejis, siekiant paspartinti valstybės ir visuomenès raidą, netinka, paskirų Ukrainos kaimynių, ES narių, patirtys byloja, kad regione galimas istoriškai kontekstualus, tinkamas hibridinio politinio režimo atvejis, realaus politinio vyksmo ir jo veiksmingumo nevertinant vien tik demokratijos, ypač tik liberalios, kriterijais, o veiksmingai taikant demokratinio ir nedemokratinio politinio valdymo principus.

Taigi D-D ryšys Ukrainoje yra trapus, priklausantis nuo daugelio vidinių ir išorinių veiksnių, skatinančių tiek demokratizacijos, tiek dedemokratizacijos procesus. Hibridiniam politiniam režimui šalyje dar toli nuo tinkamiausios valdymo formos, bet kaip tyrẻjai, būdami demokratijos vertybių ir principų šalininkai, turime formuoti tokị demokratizacijos bei dedemokratizacijos ryšį, kuris reikštų prodemokratinę hibridinio politinio režimo Ukrainoje raidą.

\section{Literatūra}

Bozóki, A., Hegedűs, D. (2018) .An externally constrained hybrid regime: Hungary in the European Union. Democratization, Vol. 25(7), p. 1173-1189. Doi: 10.1080/13510347.2018.1455664.

Brzezinski, Z. (1994). Same Roots Nourish Russia and Ukraine. New York Times, June 28, Section A, p. 16.

Carroll, O. (2018). The return of the godfather: How Putin's best friend in Ukraine is staging an improbable comeback. Prieiga internete: https:/www.independent.co.uk/news/world/europe/putin-russia-godfatherviktor-medvedchuk-us-sanctions-ukraine-politics-a8515456.html [žr. 2021-04-02].

Cassani, A. (2014). Hybrid what? Partial consensus and persistent divergences in the analysis of hybrid regimes. International Political Science Review, Vol. 35(5), p. 542-558. Prieiga internete: https://doi. org/10.1177/0192512113495756.

Collier, D., Levitsky, S. (1997). Democracy with Adjectives: Conceptual Innovation in Comparative Research. World Politics, Vol. 49 (3), p. 430-451. Retrieved March 23, 2020. Prieiga internete: www.jstor.org/ stable/25054009 [žr. 2021-04-15].

Colton, T. (2018). Regimeness, Hybridity, and Russian System Building as an Educative Project. Comparative Politics, Vol. 50(3), p. 455-473. Doi: 10.2307/26532696.

Fedorenko, K., Rybiy, O., Umland, A. (2016). The Ukrainian party system before and after the 2013-2014 Euromaidan. Europe-Asia Studies, Vol. 68(4), p. 609-630.

Fishman, R. A. (1990). Rethinking State and Regime: Sounthern Europe's Transition to Democracy. World Politics, Vol. 42, p. 422-440.

Democracy Index. (2020). In sickness and in health? A report by The Economist Intelligence Unit.

Diamond, L., Plattner, M. (1996). The global resurgence of democracy. Journal od Democracy. Baltimore, MD: Johns Hopkins University Press, p. 3-25.

Diamond, L. (2002). Thinking About Hybrid Regimes. Journal of Democracy, Vol. 13(2), p. 21-35.

Fragile States Index, Ukraine. (2020). Prieiga internete: https://fragilestatesindex.org/country-data/ [žr. 2021-03-04]. 


\section{Konstantinas Lotiuk}

Yazici, E. (2019). Nationalism and Human Rights. Political Research Quarterly, Vol. 72(1), p. 147-161. Prieiga internete: https://doi.org/10.1177/1065912918781187.

Karl, T. L. (1995). The hybrid regimes of Central America. Journal of Democracy, Vol. 6(3), p. 72-86.

Krupavičius, A., Lukošaitis, A. (2004). Lietuvos politine sistema: sqranga ir raida. Kaunas: Poligrafija ir informatika.

Kuzio, T. (1998). Ukraine: Nation and State Building. London: Routledge.

Kuzio, T. (2005). Regime type and politics in Ukraine under Kuchma. Communist and Post-Communist Studies, Vol. 38, Issue 2, p. 167-190. Prieiga internete: https://doi.org/10.1016/j.postcomstud [žr. 2005-03-07].

Laurẻnas, V. (2017). Spartèjančios visuomenès politinis režimas. Klaipèda: Klaipèdos universitetas.

Laurėnas, V. (2018). Kuri postdemokratija? In: S. Šiliauskas, K. Šerpetis (red.). Gerove ir saugumas XXI amžiuje: postdemokratijos kontekstai / Welfare and Security in 21st Century: Contexts of the Post-democracy. Klaipèdos universiteto leidykla, p. 13-80.

Linz, J. J. (1973). Totalitarian and Authoritarian Regimes. Lynne Rienner Publishers.

Lotiuk, K. (2021). C. Tilly'io demokratizacijos ir dedemokratizacijos procesų koncepcijos veiksmingumas postdemokratijos kontekste. Regional Formation and Development Studies, Nr. 33(1), p. 62-76. Doi: $10.15181 /$ rfds.v33i1.2199

Mufti, M. (2018). What Do We Know about Hybrid Regimes after Two Decades of Scholarship? Politics and Governance, Vol. 6(2), p. 112-119. Prieiga internete: Doi: 10.17645/pag.v6i2.1400

Nations in Transit. (2021). Freedom House. Prieiga internete: https://freedomhouse.org/country/ukraine/nations-transit/2021 [žr. 2021-04-16].

Prentice, A. (2018). Civil society steps in as Ukraine struggles to tame corruption. Prieiga internete: https://www. reuters.com/article/us-ukraine-corruption-ngos-idUSKCN1IX494 [žr. 2021-04-16].

Radeljić, B. (2021). The Unwanted Europeanness? Berlin, Boston: De Gruyter. Prieiga internete: https://doi. org/10.1515/9783110684216.

Statkus, N. (2003). Etniškumas ir nacionalizmas: istorinis ir teorinis aspektai. Vilnius: Vilniaus universiteto leidykla.

Stone, R. (2019). N. Ukraine Civil Society Assessment. University of Chicago. Prieiga internete: https://www.norc.org/Research/Projects/Pages/ukraine-civil-society-assessment.aspx [žr. 2021-04-01].

Tilly, C. (2003). Inequality, Democratization, and De-Democratization. Sociological Theory, Vol. 21(1), p. 37-43. Doi: $10.1111 / 1467-9558.00174$.

Tilly, C. (2007). Democracy. Cambridge University Press.

Tilly, C. (2000). Processes and Mechanisms of Democratization. Sociological Theory, Vol. 18(1), p. 1-16. Doi: $10.1111 / 0735-2751.00085$.

Ukraine Country Report. (2020). Bartelsmann Stiftung. Prieiga internete: https://www.bti-project.org/en/reports/country-report-UKR.html [žr. 2021-04-29].

IMI. (2021). Барометр свободи слова. Prieiga internete: https://imi.org.ua/monitorings/barometr-svobody-slova.

Смірнова, В. О. (2017). Гібридний режим в Україні як наслідок відсутності вольових зусиль у вищих ешелонах влади. Science and Education a New Dimension. Humanities and Social Sciences, Vol. 20, Issue 120, p. 70.

Касьянов, Г. (2018). Past Continuous: історична політика 1980-2000. Київ: Лаурус.

Лебедюк, В. (2018). Регіональні особливості динаміки розвитку політичних партій у Рівненській області. Політичні партії $i$ вибори: українські та світові практики. Випуск 2. Львів ЛНУ імені Івана Франка.

Razumkov Center. (2020). Рівень підтримки громадянами вступу України до ЄС та НАТО (січень 2020p. соціологія). Разумков Центр. Prieiga internete: http://razumkov.org.ua/napriamky/sotsiologichnidoslidzhennia/riven-pidtrymky-gromadianamy-vstupu-ukrainy-do-yes-ta-nato-sichen-2020r [žr. 2021-04-27].

DIF. (2020). Українці залучені до громадської діяльності, але уникають активної участі. Фонд Демократичні Ініціативи імені Ілька Кучеріва. Prieiga internete: https://dif.org.ua/article/ukraintsizalucheni-do-gromadskoi-diyalnosti-ale-unikayut-aktivnoi-uchasti [žr. 2021-04-24]. 


\section{FEATURES OF DEMOCRATISATION}

\section{AND DE-DEMOCRATISATION IN UKRAINE}

\section{Konstantinas Lotiuk}

Summary

The term 'hybrid political regime' is becoming more and more common in today's research into political regimes, not only in terms of the redistribution of democratisation and de-democratisation, but also in terms of their coexistence for better governance. Unable to overcome and ignore its limits, democracy in the world faces such challenges that it has found itself in a crisis. Research is full of post-democratic and neo-democratic terminology with increasing reference to hybrid political regimes. It makes sense to look at the continuity of the history of democracy, not only through the oldest prism of its 'inevitability', but also through the prism of its real effectiveness. In other words, are countries that call themselves new democracies not on the traditional path of 'pure democracy' while significant changes are already taking place in the development of democracy? Even more so that transformational processes are taking place in a consolidated democracy as well.

Therefore, our subject is the connection between the processes of democratisation and de-democratisation in Ukraine's political regime, with the aim of evaluating these processes in the context of approving or denying the assumptions and statements of the scientific discourse.

In this article, some of the principal assumptions and statements of the scientific discourse of features of de-democratisation and de-democratisation in Ukraine are evaluated:

1. The processes of democratisation and de-democratisation in Ukraine interact, not only negating and destroying one another, but also complementing and limiting extremes that hinder political stability and good governance.

2. The connection between processes of democratisation and de-democratisation in Ukraine depends on both the internal and external geopolitical situation, and could be described as having features of a hybrid political regime.

The methodological 'triangle' of the research is as follows: 1) reliance on the scientific discourse of democratisation and de-democratisation processes; 2) the index of the development of the political system in Ukraine in the period between 2004 and 2020, based on the Economist Intelligence Unit Democracy Index (EIU), the Freedom House Index (FHI), and the Bertelsmann Stiftung Transformation Index (BTI); 3) an expert survey (interview) on issues of democratisation and de- 


\section{Konstantinas Lotiuk}

democratisation processes in Ukraine. Methods: analysis of scientific literature and publication, statistical and empirical analysis, case study, semi-structural interview.

After the research, we cannot state that ongoing processes of democratisation and de-democratisation (D-D) in Ukraine are categorically negating each other. Despite this, there are insufficient arguments for the statement that the connection between D-D is purposefully constructed and maintained for better state governance. The situation is more similar to a 'grey zone'. Stating this kind of situation only affirms the first part of our first assumption, which states that processes of D-D in Ukraine interact not only as mutually negative and destructive entities, but also complementing and restricting the extremes, which interfere with good governance and political stability. Not only the geopolitical and military conflict situation, but also internal factors, such as the potential and efforts of pro-Russian forces, make Ukraine limit the institutionalisation of a 'consolidated democracy' political regime.

This is why our second assumption, that the connection between processes of democratisation and de-democratisation in Ukraine depends on both the internal and external geopolitical situations, and is described as having hybrid political regime features, is also only confirmed in its first part, and the second part needs clarification. The clarification needs to be as follows: the hybrid political regime of Ukraine is invalid when viewed from the positions of faster development. Despite this, the case of the hybrid political regime in Ukraine is not appropriate for the faster development of the state and society, but the experience of individual neighbours of Ukraine, members of the EU, shows that the historically contextual case of a hybrid political regime is regionally possible. This is the case when we do not measure the actual political process by only the criteria of liberal democracy, and effectively apply the principles of democratic and undemocratic governance.

Therefore, the connection between D-D in Ukraine is fragile and dependent on many internal and external factors that promote both processes of democratisation and de-democratisation. The hybrid political regime in Ukraine is far from a suitable form of governance, but as proponents of democratic values and principles, we have to model a connection of $\mathrm{D}-\mathrm{D}$, which would mean the pro-democratic development of a hybrid political regime in Ukraine.

Konstantinas Lotiuk - Klaipėdos universiteto Socialinių ir humanitarinių mokslų fakulteto Viešojo administravimo ir politikos mokslų katedros doktorantas.

El.paštas: konstantinas.lotiuk@gmail.com 